\title{
Substantiating velocity of amber buoying to the surface of sludge-like rock mass
}

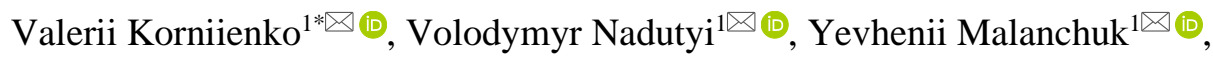 \\ Valerii Soroka $^{1 \otimes(\bullet}$, Mukhtar Yeluzakh ${ }^{2 \otimes(0)}$ \\ ${ }^{I}$ National University of Water and Environmental Engineering, Rivne, 33028, Ukraine \\ ${ }^{2}$ Satbayev University, Almaty, 50013, Kazakhstan \\ *Corresponding author: e-mail kvja@i.ua, tel.+380501014248
}

\begin{abstract}
Purpose is to substantiate the parameters and factors in terms of which amber can be mined efficiently from sand deposits using hydromechanical method.

Methods. Laboratory studies and full-scale experiments of amber-bearing sand with 2-50 mm fractions were carried out to substantiate velocity of amber buoying up to the sludge surface. Amber from Klessiv and Volodymyrets deposits were involved. Computer research relied upon Curve Fitting of the software environment Matlab. Analysis of amber particles, buoying up to the surface, relied upon a theory of particle motion within the sand formation, characterizing by motion with resistance of a dry friction type. Methods of mathematical statistics were applied; then dependences were plotted describing the effect of mining parameters on the amber buoying up velocity.

Findings. The basic parameters of hydromechanical method and parameters, effecting buoying up velocity, and dependence of dimensions as well as weight of the amber fractions have been identified. Dependences of the dominant factor effect on the process of amber buoying up to the surface of sludge-like rock mass have been determined to improve the efficiency of amber mining.
\end{abstract}

Originality. Maximum period of the analyzed amber fractions, differing in their diameters, is not longer than 4 minutes. The results of the experimental data as well as computer-based experimental data have helped define that $3^{\text {rd }}$ order polynom with corresponding rational coefficients for various amber fractions, occurring in the sand amber-bearing deposits, is the most adequate to describe the research. It has also been defined that velocity of amber buoying up from amber-bearing sand medium depends upon effect on the process of the dominant factors; and geometry of amber fractions and their weight making it possible to apply a hydromechanical mining method.

Practical implications. The obtained regularities of hydromechanical mining of sand amber deposits help calculate and select facilities for hydromechanical mining of amber.

Keywords: hydromechanical mining, deposit, amber fraction, buoying up velocity, density

\section{Introduction}

The significant amber reserves, occurring within the territory of Rivne Region (Ukraine) are under different mining and geological conditions. In terms of the prospected amber reserves, Ukraine ranks third in the world after Poland (700 thousand tons) and the Russia (160 thousand tons). Currently, six amber deposits have been prospected as well as several dozens of its manifestations. Amber finds are recorded nearly within the whole territory of Ukraine. They are numerous. Variety of characteristics and enclosing rocks need further research to improve the mining methods taking into consideration technogenic and environmental circumstances [1]-[3].

The fossil resins, occurring in different deposits of the world, are just amber-like resins. Their mining technique var- ies significantly; moreover, it is stipulated by the nature of amber-bearing rocks [4], [5].

Specific attention is concentrated on the amber being mined from sand deposits in Rivne Region. Availability of admixtures and impurities of 27-18 chemical elements is its specific feature. Currently, amber from amber-bearing deposits is mined with the help of old-fashioned methods making it possible to extract only up to $50 \%$ of the field amber. The abovementioned shows that the mining methods are inadequate while requiring implementation of new techniques and facilities in the production procedures [6]-[8].

Today, demand in raw amber has increased drastically since it is applied broadly by pharmaceutical industry, chemical industry, space industry, optical industry and other industries in addition to a jewellery one. Amber cost as well as its commer- 
cial value depends upon uniqueness of samples, their size; the characteristics are identified by means of expertise [9].

During short time, Rivne amber has found its acceptance in the domestic and the world markets. That is why improvement of its mining method using the significant factors, influencing the process, is topical [10].

Geotechnical amber mining methods become popular today since their use will help improve both methods and facilities maximizing amber output from the amber-bearing formation. Moreover, the necessity arises to develop available methods, used by production enterprises, and launch innovative ones. There are numerous commercially important amber-bearing deposits in Ukraine, being mined, and those, not being mined, due to the impossibility to develop them with the help of the traditional methods.

In the context of almost each Rivne Region deposits, amber occurs in sandy soil and sandy-clay one at a depth being almost $15 \mathrm{~m}$. The amber is mined using the two methods: mechanical and hydromechanical. However, the methods have many disadvantages, namely: high operational and economic costs; the rock outcropping; application of oldfashioned method and equipment; noncomplete mining (up to $30 \%$ ); and negative impact on the environment [11].

The research, carried out in the field of well hydromining, has helped upgrade the method of mechanical hydromining. Hydromechanical methods involve in-site amber transition to a movable condition by means of mechanical effector influence on rock mass as well as water-and air saturation of the sandy amber-bearing rock mass [12]-[14].

Further development of the tendency to upgrade hydromechanical mining with mechanical formation stimulation in a well is aimed at the process intensification owing to substantiation and selection of the intensifier type and design [15]-[17].

Industrial testing of the new method and equipment has made it possible to represent quantitative evaluation of the extraction parameters to extract amber from amber bearing deposits. The hydromechanical mining method, mastered by the industrial sites, is a promising technique since it is implemented with no breakage of a rock layer; moreover, no further recultivation of the site surface is required.

At the same time, ultra-high water consumption, which sources are limited in Rivne Region, in the context of sandy and sandy-clay deposits is one of the factors restricting wide use of the method [18]. Moreover, use of hydromechanical method has demonstrated that amber mining efficiency is also influenced heavily by a velocity of the mineral buoying up from a well which needs significant water consumption. Currently, no scientific studies are available concerning rational limitation of water use without decrease in mining efficiency. The analyses have shown that hydraulic mixture density is one of the important and efficient factors influencing heavily the amber fraction buoying out; however, nature of the influence is understudied.

The considered methods have considerable disadvantages, and need further improvement. The following can be considered as the key ones: hydraulic mining process needs huge water quantities being energy-intensive procedure at the stages of preparation and extraction; no operation of amber mining from amber-bearing medium involves its treatment since certain share of the mineral, being of different sizes, remain ungathered within a pond together with theimpurities. There is no information concerning features of further processing of sand mixture or clay mixture to extract amber from it; concerning the improved efficiency of equipment operation; and concerning the reduced energy consumption. Information is also nonavailable as for the use of innovative methods and facilities.

Complexity, numerous possible operating procedures of mining as well as specifity of deposit operations mean that amber analysis and extraction involve the necessity to carry out extra studies of the equipment systems [19], [20].

Purpose of the research is to identify dependence of the effect of dominant factors on the process of amber buoying up to the surface of sludge-like rock mass to improve the efficiency of the mineral extraction from deposits.

To prevail, it is necessary to conduct extra experiments and theoretical studies to identify dependences of factor effect on the amber bearing rock mass processing; develop amber extraction methods intended to solve a problem of improving geotechnology for amber mining under the specific conditions involving significant upgrading of the procedure taking into consideration mining and geological conditions as well as environmental demands combined with the engineering solutions to implement the proposed processes.

\section{Methods}

Complex effect of several mechanisms is used simultaneously while amber mining; for instance, development of conditions for buoying up of amber fractions, varying in their weight, in terms of additional effect by air flow (i.e. floatation or barbotage) as well as vibration effect within a working zone. Efficiency of the amber mining method may be increased owing to the selection of dominant factors of the process and their rational parameters [21]-[24].

In the general case, stress-strain state of a medium is a three-dimentional one; however, description of its characteristic features using simple models is a challenge. Nevertheless, in some cases, when the strain is uniaxial one, the material behaviour may be simulated visually and simply with certain assumptions by means of the simplest structural elements. Usually, description of rheological behaviour of medial involves mechanical models where differential of integral equations are used with various combinations of viscous, elastic, and plastic characteristics [25].

Wet sand is a dilatant non-Newtonian liquid. The fact is the process specifics. In this context, such a phenomenon will be observed as amber fraction buoying up to the surface if only density of a water-sand mixture is more than amber density. That is why the paper describes features of mathematical modeling of amber buoying up processes within the disperse media.

Using [26] studies, demonstrate the key results of solving a problem of amber particle motion within the amber-bearing medium also determining the particle velocity, and hydromechanical effect. The amber-bearing medium is thencomponent granular mixture; space between its particles may be filled with liquid or gas.

Under vibration (fast process), the certain stationary distribution of average total volume concentration of the medium particles $\left(s, \mathrm{~g} / \mathrm{m}^{3}\right) c<1$ has taken place. The concentration remains constant during a process of slow stratification of the medium components (i.e. segregation). The concentration is considered as relatively high; hence, the particles are arranged rather densely competing for the volume being occupied. Changes in location of particles, occupying the 
certain volume, take place in the form of substitution for other particles having similar total volume.

The abovementioned places definite restrictions on granulometric composition of the considered mixtures [27]. Vibration is expected as rather intensive process; thus, pseudofluidization effect of the mixture takes place [28].

The process of amber buoying up to the surface is implemented relying upon the analysis of particle motion within the sand formation; it is characterized by motion with resistance of a dry friction type. Motion of amber particle, placed in the medium performing horizontal translating oscillations with $\omega$ frequency and $r$ trajectory radius, resists the particle in the form of dry friction. A relevant problem was considered by V.V. Hortynsky, H.Ye. Ptushkina, I.I. Bliekhman, and Z.R. Malanchuk [29].

The considered studies have been generalized by the case when there are slow spatial flows of all the fractions as a sole medium characterized by a velocity, depending upon spatial coordinates, i.e. velocity of transfer motion of the medium. The process simulation involves the assumptions that the coordinate functions are of scalar nature; moreover, they are varied by means of a vector.

The paper represents more detailed analysis of simulation of the process of amber particle buoying up within the amber-bearing medium.

Relying upon the studies, theoretical data array has been obtained. The array is represented by means of buoying velocity dependences upon the effect of dominant factors. Fullscale studies have helped obtain experimental data array to be compared with computer simulation data. Below, you can find the derived approximating dependences.

To substantiate a velocity of amber buoying up to the sludge surface, laboratory experiments as well as full-scale studies have been carried out to analyze amber-bearing 2-50 mm fraction sand from Klessiv and Volodymyrets amber deposits using various influence factors to determine the key ones favouring maximum buoying up velocity. The experimental results concerning amber grade and its distribution within the amber-bearing formation are close to auditing data by Rivne geological expedition of Pivnichgeologia SE as for the amber deposits in the region.

The research is based upon Curve Fitting of Matlab software environment. The mathematical model adequacy has been verified using comparison between the mathematical simulation and experimental data based upon the full-scale facilities.

\section{Results and discussion}

The mathematical simulation was implemented to obtain adequate mathematical model of amber particle buoying up within the sand-water mixture relying upon the carried out numerical experiments with particles having different sizes within the media varying in their density as well as plot dependences based upon the operational features of amber mining under different physical conditions. The computer experiment has helped identify that following $f(x)$ function with $3^{\text {rd }}$ order polynom describes the most adequately experimental data represented in Table 1:

$f(x)=a x^{3}+b x^{2}+c x+d$,

where:

$a, b$, and $c$ - regression coefficients; $x$ - a variable.

In terms of the each cases, optimal $a, b, c$, and $d$ coefficients have been selected to plot dependences of buoying up velocity upon variable parameters of the system.

In terms of the research results, the curves (Fig. 1), obtained by means of computer simulation, have been plotted basing upon the experimental research data under the conditions of amber-bearing deposit (Table 1).

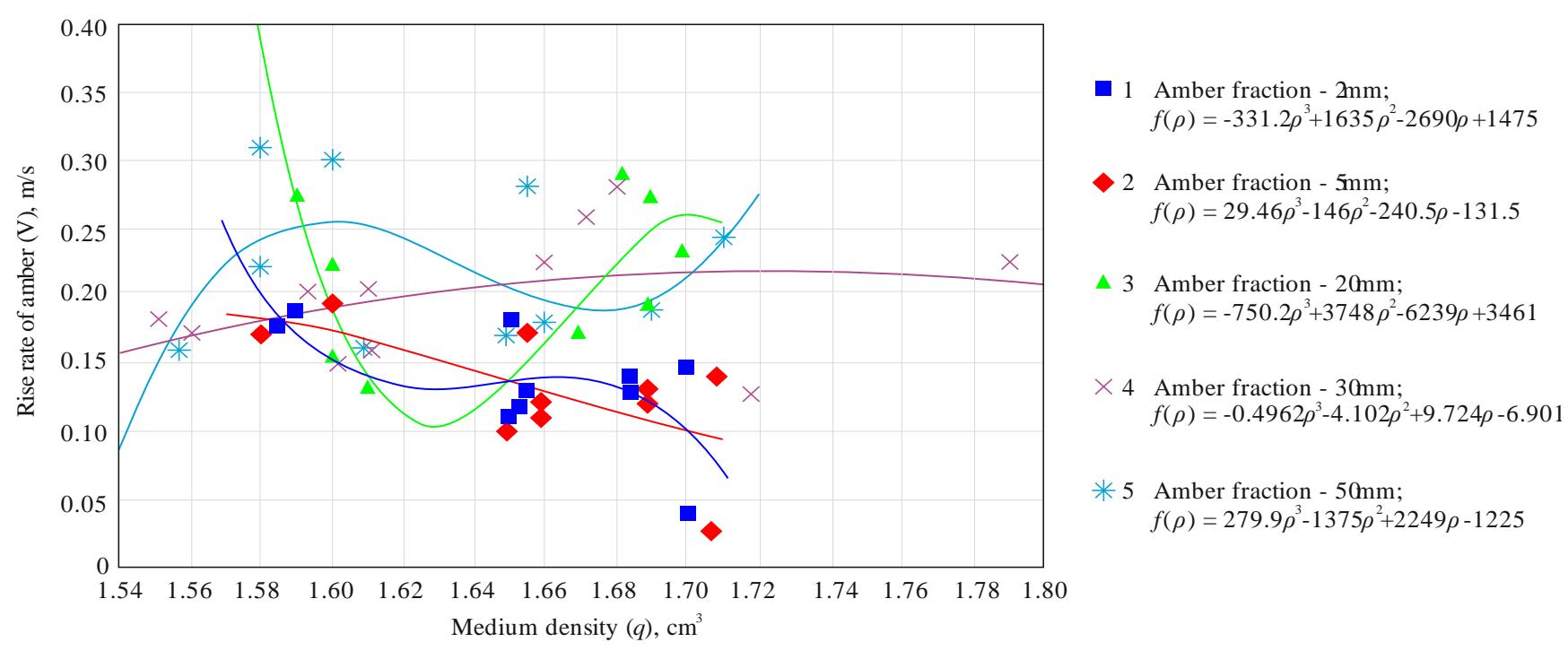

Figure 1. Dependence of amber buoying up velocity upon medium density: $f(\rho)$ is the buoying up velocity, $m / s ;$ and $\rho$ is the medium density, $\mathrm{g} / \mathrm{cm}^{3}$

Predictive dependence of amber buoying up velocity within the studied amber-bearing sand has been plotted in terms of sizes of fractions (Fig. 2).

Function of the derived dependence is as follows:

$$
f(d)=8.117 \cdot 10^{-06} d^{3}-0.000697 d^{2}+0.0171 d+0.0893,(2)
$$

where:

$f(d)$ - buoying up velocity, $\mathrm{m} / \mathrm{s}$;

$d$ - fraction sizes, mm.

Experiments used amber pieces covered mostly by an oxide dark-brown film; the amber density was $1.24 \mathrm{~g} / \mathrm{cm}^{3}$ with $5 \mathrm{~mm}$ size. 
Table 1. Fragment of the experimental database to identify amber buoying up velocity $\left(V_{r i}\right)$

\begin{tabular}{|c|c|c|c|c|c|}
\hline \multicolumn{2}{|c|}{ Buoying up velocity, $V_{r i}, \mathrm{~m} / \mathrm{s}$} & \multirow{2}{*}{$\begin{array}{c}\text { Vibration } \\
\text { frequency, } \omega, \mathrm{Hz}\end{array}$} & \multirow{2}{*}{$\begin{array}{c}\text { Medium } \\
\text { density, } \rho, \mathrm{g} / \mathrm{cm}^{3}\end{array}$} & \multirow{2}{*}{$\begin{array}{c}\text { Oscillation } \\
\text { amplitude, } A, \mathrm{~mm}\end{array}$} & \multirow{2}{*}{$\begin{array}{c}\text { Air supply, } \\
q, \mathrm{~cm}^{3} / \mathrm{s}\end{array}$} \\
\hline analytical & experimental & & & & \\
\hline \multicolumn{6}{|c|}{$2 \mathrm{~mm}$ fraction } \\
\hline 0.11 & $0.104 ; 0.108 ; 0.102$ & 20 & 1.650 & $2.47 ; 2.09 ; 2.44$ & 1.1111 \\
\hline 0.12 & $0.11 ; 0.115 ; 0.114$ & 21 & 1.653 & $2.25 ; 2.22 ; 2.23$ & 1.1111 \\
\hline 0.132 & $0.130 ; 0.142 ; 0.144$ & 22 & 1.655 & $1.50 ; 1.55 ; 1.52$ & 1.1111 \\
\hline 0.14 & $0.144 ; 0.148 ; 0.150$ & 23 & 1.684 & $1.20 ; 1.22 ; 1.24$ & 1.1111 \\
\hline 0.15 & $0.171 ; 0.150 ; 0.154$ & 25 & 1.700 & $1.00 ; 0.98 ; 1.1$ & 1.1111 \\
\hline 0.18 & $0.195 ; 0.22 ; 0.189$ & 28 & 1.650 & $2.47 ; 2.45 ; 2.44$ & 1.6667 \\
\hline 0.19 & $0.190 ; 0.199 ; 0.195$ & 30 & 1.590 & $2.25 ; 2.24 ; 2.23$ & 1.6667 \\
\hline 0.18 & $0.187 ; 0.188 ; 0.182$ & 33 & 1.585 & $1.50 ; 1.49 ; 1.49$ & 1.6667 \\
\hline 0.13 & $0.150 ; 0.142 ; 0.130$ & 35 & 1.684 & $1.20 ; 1.221 .23$ & 1.6667 \\
\hline 0.04 & $0.05 ; 0.051 ; 0.041$ & 37 & 1.700 & $1.00 ; 1.1 ; 1.1$ & 1.6667 \\
\hline \multicolumn{6}{|c|}{$5 \mathrm{~mm}$ fraction } \\
\hline 0.10 & $0.11 ; 0.118 ; 0.112$ & 20 & 1.649 & $2.45 ; 2.49 ; 2.45$ & 1.1331 \\
\hline 0.11 & $0.12 ; 0.125 ; 0.121$ & 21 & 1.659 & $2.20 ; 2.20 ; 2.23$ & 1.1336 \\
\hline 0.12 & $0.120 ; 0.122 ; 0.124$ & 22 & 1.659 & $1.52 ; 1.58 ; 1.58$ & 1.1337 \\
\hline 0.13 & $0.134 ; 0.132 ; 0.130$ & 23 & 1.689 & $1.21 ; 1.21 ; 1.21$ & 1.1338 \\
\hline 0.14 & $0.131 ; 0.140 ; 0.143$ & 25 & 1.709 & $1.05 ; 0.99 ; 1.11$ & 1.1339 \\
\hline 0.17 & $0.185 ; 0.192 ; 0.190$ & 28 & 1.655 & $2.59 ; 2.58 ; 2.48$ & 1.697 \\
\hline 0.19 & $0.210 ; 0.209 ; 0.195$ & 30 & 1.600 & $2.23 ; 2.23 ; 2.22$ & 1.698 \\
\hline 0.17 & $0.177 ; 0.178 ; 0.179$ & 33 & 1.580 & $1.52 ; 1.50 ; 1.49$ & 1.699 \\
\hline 0.12 & $0.110 ; 0.112 ; 0.110$ & 35 & 1.689 & $1.20 ; 1.22 ; 1.22$ & 1.699 \\
\hline 0.03 & $0.05 ; 0.051 ; 0.041$ & 37 & 1.707 & $1.00 ; 1.10 ; 1.11$ & 1.699 \\
\hline \multicolumn{6}{|c|}{$10 \mathrm{~mm}$ fraction } \\
\hline 0.15 & $0.16 ; 0.165 ; 0.166$ & 20 & 1.60 & $2.47 ; 2.51 ; 2.55$ & 1.1320 \\
\hline 0.17 & $0.17 ; 0.17 ; 0.171$ & 21 & 1.67 & $2.22 ; 2.21 ; 2.22$ & 1.1321 \\
\hline 0.19 & $0.200 ; 0.202 ; 0.203$ & 22 & 1.689 & $1.50 ; 1.51 ; 1.51$ & 1.1321 \\
\hline 0.23 & $0.234 ; 0.233 ; 0.231$ & 23 & 1.699 & $1.22 ; 1.24 ; 1.23$ & 1.1325 \\
\hline 0.24 & $0.231 ; 0.240 ; 0.245$ & 25 & 1.719 & $1.15 ; 1.09 ; 1.10$ & 1.1329 \\
\hline 0.27 & $0.259 ; 0.242 ; 0.250$ & 28 & 1.69 & $2.60 ; 2.61 ; 2.62$ & 1.60 \\
\hline 0.29 & $0.260 ; 0.269 ; 0.255$ & 30 & 1.68 & $2.13 ; 2.13 ; 2.11$ & 1.60 \\
\hline 0.27 & $0.277 ; 0.278 ; 0.279$ & 33 & 1.590 & $1.52 ; 1.51 ; 1.40$ & 1.60 \\
\hline 0.22 & $0.220 ; 0.222 ; 0.220$ & 35 & 1.60 & $1.25 ; 1.27 ; 1.27$ & 1.601 \\
\hline 0.13 & $0.150 ; 0.131 ; 0.141$ & 37 & 1.61 & $1.11 ; 1.11 ; 1.12$ & 1.601 \\
\hline \multicolumn{6}{|c|}{$30 \mathrm{~mm}$ fraction } \\
\hline 0.15 & $0.15 ; 0.148 ; 0.152$ & 20 & 1.60 & $2.40 ; 2.41 ; 2.41$ & 1.1233 \\
\hline 0.16 & $0.164 ; 0.165 ; 0.161$ & 21 & 1.61 & $2.20 ; 2.20 ; 2.20$ & 1.1233 \\
\hline 0.17 & $0.170 ; 0.172 ; 0.174$ & 22 & 1.559 & $1.50 ; 1.50 ; 1.51$ & 1.1233 \\
\hline 0.18 & $0.184 ; 0.182 ; 0.180$ & 23 & 1.549 & $1.22 ; 1.22 ; 1.21$ & 1.1233 \\
\hline 0.20 & $0.201 ; 0.200 ; 0.203$ & 25 & 1.609 & $1.15 ; 1.19 ; 1.14$ & 1.1233 \\
\hline 0.22 & $0.220 ; 0.210 ; 0.190$ & 28 & 1.659 & $2.49 ; 2.48 ; 2.48$ & 1.690 \\
\hline 0.25 & $0.250 ; 0.259 ; 0.255$ & 30 & 1.670 & $2.43 ; 2.43 ; 2.44$ & 1.693 \\
\hline 0.27 & $0.277 ; 0.278 ; 0.279$ & 33 & 1.680 & $1.42 ; 1.40 ; 1.42$ & 1.694 \\
\hline 0.22 & $0.220 ; 0.222 ; 0.220$ & 35 & 1.79 & $1.30 ; 1.32 ; 1.32$ & 1.695 \\
\hline 0.13 & $0.15 ; 0.151 ; 0.161$ & 37 & 1.717 & $1.20 ; 1.19 ; 1.19$ & 1.696 \\
\hline \multicolumn{6}{|c|}{$50 \mathrm{~mm}$ fraction } \\
\hline 0.16 & $0.15 ; 0.158 ; 0.162$ & 20 & 1.609 & $2.47 ; 2.47 ; 2.45$ & 1.1339 \\
\hline 0.17 & $0.173 ; 0.175 ; 0.176$ & 21 & 1.649 & $2.21 ; 2.22 ; 2.23$ & 1.1339 \\
\hline 0.18 & $0.180 ; 0.182 ; 0.184$ & 22 & 1.659 & $1.55 ; 1.58 ; 1.58$ & 1.1339 \\
\hline 0.19 & $0.194 ; 0.202 ; 0.200$ & 23 & 1.690 & $1.22 ; 1.21 ; 1.25$ & 1.1339 \\
\hline 0.24 & $0.231 ; 0.244 ; 0.244$ & 25 & 1.711 & $1.15 ; 1.19 ; 1.14$ & 1.1339 \\
\hline 0.28 & $0.289 ; 0.292 ; 0.290$ & 28 & 1.655 & $2.50 ; 2.51 ; 2.49$ & 1.699 \\
\hline 0.30 & $0.310 ; 0.309 ; 0.305$ & 30 & 1.600 & $2.20 ; 2.21 ; 2.22$ & 1.699 \\
\hline 0.31 & $0.317 ; 0.308 ; 0.309$ & 33 & 1.580 & $1.50 ; 1.50 ; 1.48$ & 1.698 \\
\hline 0.22 & $0.223 ; 0.222 ; 0.220$ & 35 & 1.580 & $1.21 ; 1.23 ; 1.22$ & 1.697 \\
\hline 0.16 & $0.155 ; 0.159 ; 0.149$ & 37 & 1.557 & $1.06 ; 1.11 ; 1.12$ & 1.695 \\
\hline
\end{tabular}

The following is considered as variables:

$-\omega$ is vibration frequency, $20-37 \mathrm{~Hz}$;

$-\rho$ is medium density, $1.60-1.75 \mathrm{~g} / \mathrm{cm}^{3}$;
$-A$ is a mean square value of the vibration amplitude, 1.00-2.47 mm;

$-q-$ air volume for barbotage, 1.11 and $1.70 \mathrm{~cm}^{3} / \mathrm{s}$. 


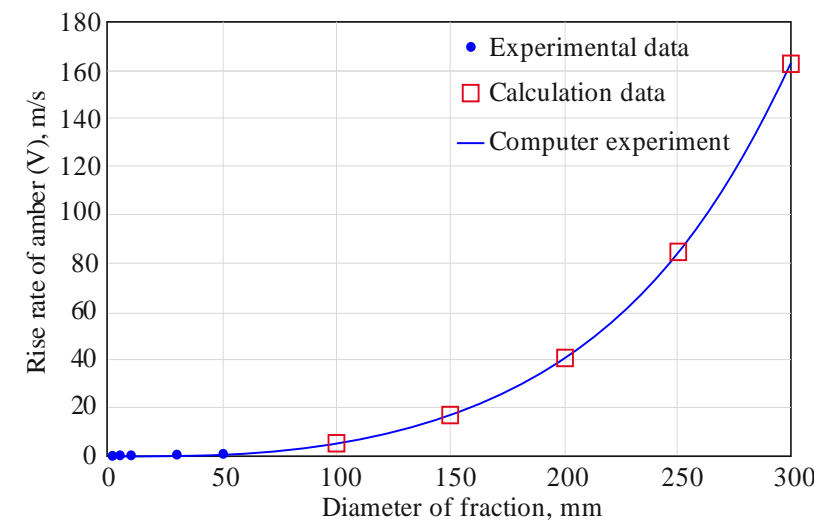

Figure 2. Predicting dependence of buoying up velocity upon a fraction size

Dependence (3) is the calculation formula to identify amber fraction velocity within suspensions $(V)$ :

$$
x V=\frac{g \Delta d}{v} \frac{m^{4.75}}{18+0.6 \sqrt{\frac{g \Delta d^{3}}{v^{2}} m^{4.75}}},
$$

where:

$g$ - gravity factor, $981 \mathrm{~cm}^{2} / \mathrm{s}$

$\frac{g \Delta d^{3}}{v^{2}}=A r-$ Archimedes criterion;

$\Delta$-dimensionless criterion taking into consideration a particle velocity and diameter within the medium;

$v$ - kinematic viscosity, $\mathrm{cm}^{2} / \mathrm{s}$;

$m$ - volume content of liquid phase;

$d$-amber fraction diameter within the sludge, $\mathrm{mm}$.

Formula (3) is applied if $m>0.6$. Moreover, it is applicable when sludge density is $1.3-1.7 \mathrm{~g} / \mathrm{cm}^{3}$. According to [30] study, $1.4-1.6 \mathrm{~g} / \mathrm{cm}^{3}$ is the rational density to achieve maximum velocity of amber buoying up.

The maximum amber buoying up velocity $(V)$, calculated using (3), is $0.2 \mathrm{~m} / \mathrm{s}$ in terms of $\rho=1.6 \mathrm{~g} / \mathrm{cm}^{3}$ medium density; $q=1.11 \mathrm{~cm}^{3} / \mathrm{s}$ air supply; $\omega=30 \mathrm{~Hz}$ vibration frequency; and $A=2 \mathrm{~mm}$ oscillation amplitude. It is not expedient for sludge density to be more than $1.6 \mathrm{~g} / \mathrm{cm}^{3}$ since it will not result in the additional acceleration of amber buoying up.

The following should be mentioned concerning amplitude and vibration frequency effect on the amber buoying up velocity: nonlinear dependence is available between amplitude and frequency; namely, increase in one of them results in the increase of another one which lasts up to the certain moment when frequencies of the forced oscillations of the system coincide with natural ones. For instance, in terms of a nonlinear area, frequency increases and amplitude remains almost constant. A process of vibration effect on pulp is connected with the energy by a vibrator motor as well as energy which may be "assimilated" by a medium starting to pass oscillation in terms of certain frequencies.

Regression equations with a range of rational parameters have been derived for different amber fractions. However, the studies are not sufficient to provide complete information concerning amber buoying up using the facilities where processes within the medium are simulated. Analysis of influence factors should be specified for the equipment operating under different geological conditions as well as facilities varying in its design. However, numerical values of the dom- inant factors are almost within one and the same range. The abovementioned helps draw the key conclusion: additional influence factors make it possible to perform 2 or even 3 times acceleration of amber buoying up.

The results of comparison of simulation data of amber buoying up from amber-bearing formation to the sludge surface with experimental data have helped develop a mathematical model to describe amber buoying up processes within a sludge-like medium. The mathematical model accuracy is $66-89 \%$.

Hence, the research has identified that amber buoying up velocity depends upon geometry as well as upon weight of amber fractions. In this context, amber buoying up velocity is of exponential nature with $3^{\text {rd }}$ order polynom. Regression equations have been obtained to determine amber buoying up velocity taking into consideration changes in the medium density under vibration effect and air barbotage. Comparative analysis of theoretical studies and experimental data has made it possible to derive regression analysis with high approximation level and plot dependences of amber buoying up velocity upon the sizes of amber fractions as well as effect of influence factors upon the amber buoying up process.

\section{Conclusions}

The key tendency to develop and improve amber mining method is implementation of a well mechanical and hydraulic technique to extract amber from sandy amber-bearing deposits using water, air, and vibration as the basic influence factors.

The research has identified that amber buoying up velocity from amber-bearing sandy medium depends upon the action of influencing factors, geometry, and weight of amber fractions making it possible to apply a hydromechanical mining method.

Maximum time for the analyzed buoying up amber fractions, being of various diameters, is not longer than four minutes. Additional influence factors help perform 2 or even 3 times buoying up acceleration. The effect by the amplitude, vibration frequency, and air consumption on the amber buoying up velocity results in its increase in terms of complex action. Nonlinear dependence is available between the amplitude and frequency; namely, increase in one of them results in the increase of another one which lasts up to certain moment when frequencies of the forced oscillations of the system coincide with natural ones. It has been identified according to the experimental data and computer experiment that $3^{\text {rd }}$ order polynom of $f(\rho)=a \rho^{3}+b \rho^{2}+c \rho+d$ type with corresponding coefficients for different amber fractions, occurring within the amber-bearing deposits, is the most adequate one to describe the experimental studies.

\section{Acknowledgements}

The research would have been impossible without support and assistance by P.P. Bortnyk, Director of Rafalivskyi karier PJSC.

\section{References}

[1] Bulat, A., Naduty, V., \& Korniyenko, V. (2014). Substantiations of technological parameters of extraction of amber in Ukraine. American Journal of Scientific and Educational Research, 5(2), 591-597.

[2] Belichenko, O., \& Ladzhun, J. (2016). Complex gemological research of new types of treated amber. Visnyk of Taras Shevchenko National University of Kyiv. Geology, 4(75), 30-34. https://doi.org/10.17721/1728$\underline{2713.75 .04}$ 
[3] Natkaniec-Nowak, L., Dumańska-Słowik, M., Naglik, B., Melnychuk, V., Krynickaya, M. B., Smoliński, W., \& Ładoń, K. (2017). Depositional environment of Paleogen amber-bearing quartzglauconite sands from Zdolbuniv (Rivne region, NW Ukraine): mineralogical and petrological evidences. Gospodarka Surowcami Mineralnymi, 33(4), 45-62. https://doi.org/10.1515/gospo-2017-0041

[4] Alekseev, V.I. (2013). The beetles Baltic amber: The checklist of described species and preliminary analysis of biodiversity. Zoology and Ecology, 23(1), 5-12. https://doi.org/10.1080/21658005.2013.769717

[5] Zakharenko, A.M., \& Golokhvast, K.S. Using confocal laser scanning microscopy to study fossil inclusion in Baltic amber, a new approach. Key Engineering Materials, (806), 192-196. https://doi.org/10.4028/www.scientific.net/KEM.806.192

[6] Malanchuk, Z., Moshynskyi, V., Malanchuk, Y., \& Korniienko, V. (2018). Physico-mechanical and chemical characteristics of amber. Solid State Phenomena, (277), 80-89. https://doi.org/10.4028/www.scientific.net/ssp.277.80

[7] Zabyelina, Y., \& Kalczynski, N. (2020). Shadowy deals with "sunny stone": Organized crime, informal mining, and the illicit trade of amber in Ukraine. Illegal Mining, 241-272. https://doi.org/10.1007/978-3030-46327-4_9

[8] Łazowski, L. (2007). The comments regarding usage and conservation of the amber resources. Przeglad Geologiczny, 55(8), 670-672.

[9] Malanchuk, Z., Moshynskyi, V., Malanchuk, V., Korniienko, Y., \& Koziar, M. (2020). Results of research into the content of rare earth materials in man-made phosphogypsum deposits. Key Engineering Materials, (844), 77-87. https://doi.org/10.4028/www.scientific.net/kem.844.77

[10] Yakymchuk, N.A., Levashov, S.P., \& Korchagin, I.N. (2019). New evidence of amber endogenous genesis. $18^{\text {th }}$ International Conference on Geoinformatics - Theoretical and Applied Aspects. https://doi.org/10.3997/2214-4609.201902017

[11] Korniyenko, V.Ya., Malanchuk, E.Z., Soroka, V.S., \& Khrystyuk, A.O. (2018). Analysis of the existent technologies of amber mining. Resources and Resource-Saving Technologies in Mineral Mining and Processing, 209-232.

[12] Krek, A., Ulyanova, M., \& Koschavets, S. (2018). Influence of landbased Kaliningrad amber mining on coastal zone. Marine Pollution Bulletin, (131), 1-9. https://doi.org/10.1016/j.marpolbul.2018.03.042

[13] Poulin, J., \& Helwig, K. (2016). The characterization of amber from deposit sites in western and northern Canada. Journal of Archaeological Science: Reports, (7), 155-168. https://doi.org/10.1016/j.jasrep.2016.03.037

[14] Xing, Q.Y., Yang, M., Yang, H.X., \& Zu, E.D. (2013). Study on the gemological characteristics of amber from Myanmar and Chinese Fushun. Key Engineering Materials, (544), 172-177. https://doi.org/10.4028/www.scientific.net/KEM.544.172

[15] Zhu, W.C., \& Wei, C.H. (2010). Numerical simulation on mininginduced water inrushes related to geologic structures using a damagebased hydromechanical model. Environmental Earth Sciences, 62(1), 43-54. https://doi.org/10.1007/s12665-010-0494-6

[16] Lemos, J.V., \& Lorig, L.J. (2020). Hydromechanical modelling of jointed rock masses using the Distinct Element Method. Mechanics of Jointed and Faulted Rock, 605-612. https://doi.org/10.1201/9781003078975-85

\section{Обгрунтування швидкості спливання бурштину на поверхню пульпоподібної гірничої маси}

\section{В. Корнієнко, В. Надутий, Є. Маланчук, В. Сорока, М. Слузах}

Мета. Проаналізований процес вилучення бурштину гідромеханічним способом. Визначені та обгрунтовані параметри й фактори, при яких процес видобутку бурштину з піщаних родовищ гідромеханічним способом $є$ найбільш ефективним.

Методика. Для обгрунтування швидкості спливання бурштину на поверхню гідропульпи проведені експериментальні лабораторні та натурні дослідження бурштиновмісного піску з фракціями 2-50 мм з Клесівського та Володимирецького родовищ бурштину. Використовуючи методи математичної статистики, отримані залежності, що описують вплив параметрів видобутку на швидкість підйому бурштину.

Результати. Визначено основні параметри гідромеханічного методу та фактори, які впливають на швидкість спливання бурштину, залежність розмірів і маса фракцій бурштину. Встановлені залежності впливу домінуючих факторів на процес спливання бурштину на поверхню пульпоподібної гірничої маси для підвищення ефективності вилучення бурштину з родовищ.

Наукова новизна. Дослідженнями встановлено, що швидкість спливання бурштину з бурштиновмісного піщаного середовища залежить від впливу на процес домінуючих факторів, розмірів та маси фракцій бурштину, що робить можливим застосування гідромеханічного способу його видобутку. Максимальний час спливання досліджуваних фракцій бурштину різних діаметрів не перевищує 4 хв. За результатами наведених експериментальних даних та комп’ютерного експерименту встановлено, що найбільш адекватно експериментальні дослідження описуються поліномом 3-ого порядку з відповідними оптимальними коефіцієнтами для різних фракцій бурштину, які мають місце в піщаних бурштиновмісних родовищах.

Практична значимість. Визначенні закономірності гідромеханічного видобутку з піщаних родовищ бурштину та визначені залежності, що дозволяють розрахувати й підібрати обладнання для гідромеханічного видобутку бурштину.

Ключові слова: гідромеханичний видобуток, родовище, фракиї̈ буритину, швидкість спливання 


\section{Обоснование скорости всплытия янтаря на поверхность пульпоподобной горной массы}

\section{В. Корниенко, В. Надутый, Е. Маланчук, В. Сорока, М. Елузах}

Цель. Проанализирован процесс извлечения янтаря гидромеханическим способом. Определены и обоснованы параметры и факторы, при которых процесс добычи янтаря из песчаных месторождений гидромеханическим способом является наиболее эффективным.

Методика. Для обоснования скорости всплытия янтаря на поверхность гидропульпы проведены экспериментальные лабораторные и натурные исследования янтаресодержащего песка с фракциями 2-50 мм с Клесовского и Владимирецкого месторождений янтаря. Используя методы математической статистики, получены зависимости, описывающие влияние параметров добычи на скорость подъема янтаря.

Результаты. Определены основные параметры гидромеханического метода и факторы, влияющие на скорость всплытия янтаря, зависимость размеров и масса фракций янтаря. Установлены зависимости влияния доминирующих факторов на процесс всплытия янтаря на поверхность пульпоподобной горной массы для повышения эффективности извлечения янтаря с месторождений.

Научная новизна. Исследованиями установлено, что скорость всплытия янтаря с янтаресодержащей песчаной среды зависит от влияния на процесс доминирующих факторов, размеров и массы фракций янтаря, что делает возможным применение гидромеханического способа его добычи. Максимальное время всплытия исследуемых фракций янтаря различных диаметров не превышает 4 мин. По результатам приведенных экспериментальных данных и компьютерного эксперимента установлено, что наиболее адекватно экспериментальные исследования описываются полиномом 3-го порядка с соответствующими оптимальными коэффициентами для разных фракций янтаря, которые имеют место в песчаных янтаресодержащих месторождениях.

Практическая значимость. Определены закономерности гидромеханической добычи песчаных месторождений янтаря и определены зависимости, позволяющие рассчитать и подобрать оборудование для гидромеханической добычи янтаря.

Ключевые слова: гидромеханическая добыча, месторождение, фракиия янтаря, скорость всплытия

\section{Article info}

Received: 11 May 2020

Accepted: 16 November 2020

Available online: 7 December 2020 